\title{
"Altogether Unproductive of Profit": A History of the First Prince Edward Island Steam Navigation Company
}

\section{H.T. Holman}

La Prince Edward Island Steam Navigation Company a été créée afin d'assurer des communications fiables et en temps opportun entre les colonies du détroit de Northumberland, dans le sud du golfe du SaintLaurent. Fondée en 1842, la société bénéficiait d'un vaste soutien communautaire de la part des constructeurs de navires et des marchands et, plus important encore, de la participation du gouvernement de la colonie en tant que propriétaire. Bien que la participation directe du gouvernement colonial ait fourni le capital nécessaire à l'entreprise, les attentes en matière de service aux ports non rentables ont entravé la capacité de la société de gérer ses opérations et ont contribué à son échec après cinq ans. Malgré son quasi-monopole sur le service de navigation à vapeur dans la région, la société était vouée à l'échec en raison de la capacité excédentaire et des coûts d'exploitation élevés.

The development of the steamship provided new opportunities for trade and communications between the Atlantic colonies of British North America during the 1830s and 40s. The period also gave rise to new mechanisms for ownership and financing and for new models of partnership, including the direct involvement of government in commercial activity.

In his 1995 essay on Canadian maritime history Lewis Fischer noted an absence of research on Canadian shipping companies. ${ }^{1}$ The situation has not changed

1 Lewis R. Fischer, "The Enterprising Canadians," in Frank Broeze, ed., Maritime History at the Crossroads: A Critical View of Recent Historiography (St. John's: Memorial University of Newfoundland, Research in Maritime History 9, 1995), 35.

The Northern Mariner / Le marin du nord, XXX, No. 1 (Spring 2020), 23-44 
significantly in the ensuing years. Such research as existed at that time, and that which has published since, tends to concentrate on larger and more successful enterprises, especially carriers which were associated with larger than life characters such as Samuel Cunard or Hugh Allen. Yet in the period prior to 1850 , characterized by experiment and initiative, it was often smaller business ventures that tested the waters of steam based commerce - and not always successfully. Sarah Palmer, discussing early mercantile steamship construction, stresses the importance of examining the role that economic and operating considerations played at a time when lack of progress in steam technology resulted in few striking advances beyond increases in size and power. ${ }^{2}$ While her observation related to the construction of vessels, the same factors may apply when examining the development of companies involved in operating these vessels. It was a period when changing financing and operating considerations often outweighed technological advances and perhaps for that reason has attracted less examination from scholars.

The Prince Edward Island Steam Navigation Company was a relatively short lived and ultimately unsuccessful attempt to harness steam power to meet the transportation needs of the community. ${ }^{3}$ Unlike some ventures, it did not exist as an outgrowth or expansion of an existing sail-based mercantile enterprise. However, the challenges posed by the new technology, and the responses of the company to them, shed light on factors which existed in many ports within the region at the time. The history of the company provides a case study of the challenges posed as new ways of doing business were applied to mercantile shipping in a colonial context. This paper reviews the thinking that lay behind the development of the PEI Steam Navigation Company, its lack of success, and the insight it provides into the limitations of the shift toward a new business model.

Within the region, the Northumberland Strait defined Prince Edward Island. The benefit of a relatively narrow and protected water route for mails, passengers and goods was limited. Blocked by winter ice, the Island was isolated for a third of the year. Communication between the colony and the mainland became one of the recurring themes of the Island's history and ran beneath the larger issues, both political and economic. For the most part, until incorporated into the Confederation agreement as "continuous steam communication," the issue of connection with the other colonies has been largely ignored by historians. ${ }^{4}$ For the Islanders themselves

\footnotetext{
2 Sarah Palmer, "Experience, Experiment and Economics: Factors in the Construction of Early Merchant Steamships," in Keith Matthews and Gerald Panting, eds., Ships and Shipbuilding in the North Atlantic Region (St. John's: Memorial University of Newfoundland, 1978), 234.

3 The Prince Edward Island Steam Navigation Company is often confused with a second, but unconnected, company with the same name that came into being in 1863 and was incorporated a year later. The second company had a very different and much more successful life.

4 Much of the writing on $18^{\text {th }}$ and $19^{\text {th }}$ century Prince Edward Island has been thematic rather than general. Political history, Confederation, and the land question dominate the research publications for the period. One of the few general histories, Francis Bolger's Canada's Smallest Province (Charlottetown: Prince Edward Island 1973 Centennial Commission, 1973), has a chapter devoted to communications but it examines developments only after 1873 and focusses on the winter service.
} 


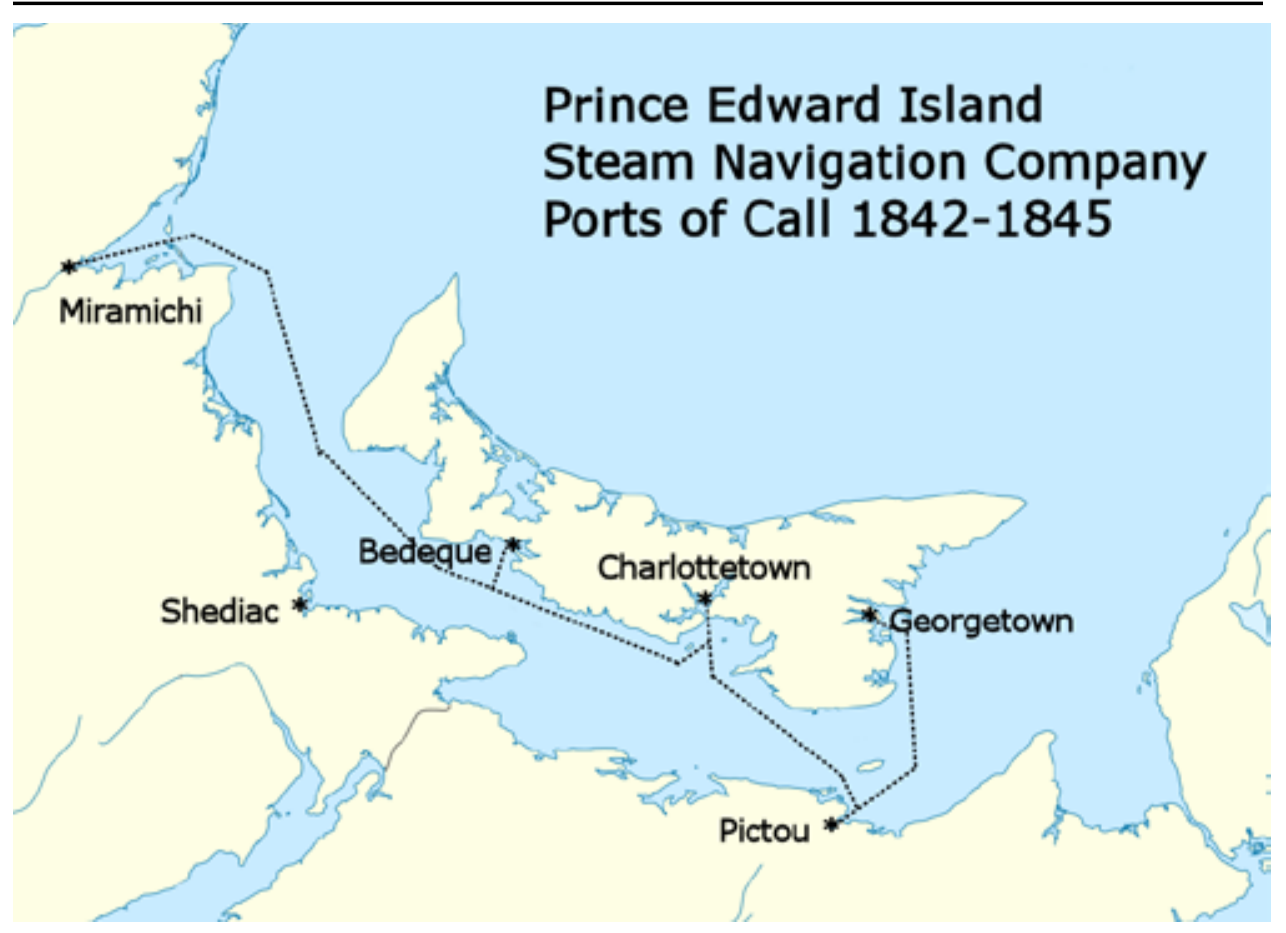

the passage across the Strait governed their relations with the rest of the world. Initially, steam travel in the Strait was concentrated in the hands of Nova Scotia merchants and companies and the Island was not always well served by the new technology available. Could the Islanders do better if they took control? This paper examines one early attempt by islanders to manage their own communications and transportation during the transition from wood and wind to iron, steel and steam.

The colony of Prince Edward Island had been slow in developing. Although it possessed considerable advantage for agricultural production in some areas, growth had been retarded by an unusual land tenure system which saw almost all of the colony granted to absentee landholders, only a few of whom had actively developed their allotments. The early years of the colony saw a boom in timber export and shipbuilding but by the 1840s agriculture had become the most significant activity. Other than timber and vessels, both of which were mainly sent across the Atlantic, exports consisted almost exclusively of agricultural products and almost all of that was sent to the neighbouring colonies of New Brunswick, Nova Scotia and Newfoundland. This usually took the form of bulk cargo and

There is relatively little writing on the pre-confederation communications between Prince Edward Island and the mainland. One exception, and this in the context of general communications in the region, is J.S. Martell's "Intercolonial Communications, 1840-1867," in Report of the Canadian Historical Association (Ottawa: 1938), 41-61, reprinted in G.A. Rawlyk, ed., Historical Essays on the Atlantic Provinces (Toronto: McClelland \& Stewart, Carleton Library 35, 1967), 179-206. While providing a good overview the paper contains a number of errors as regards the Steam Navigation Company. 
was carried by a coastal fleet of schooners and other small rigs. The population in 1841 had reached 47,000 and although it was to grow by a third in the next seven years there were few large settlements. Charlottetown had about 4000 residents but numbers in most rural areas showed a low density with few towns or villages. ${ }^{5}$ Protected harbours were found at a number of locations but Charlottetown, the centre of government, Georgetown, a county town in the eastern part of the colony, and Bedeque which in 1840 was a district rather than a community, were the main shipping points.

Cut off from the mainland by ice for four to five months each year, the Island looked across Northumberland Strait to equally small communities on the coast of New Brunswick and Nova Scotia, a shore that was somewhat remote from the commercial centres of Halifax and Saint John and was connected to them by poorly developed post roads and stage lines. With limited traffic across the Strait, steam service to the colony developed by fits and starts and at a much later date than in neighbouring colonies. ${ }^{6}$ It was not until May 1830 that Prince Edward Island had entered the steam age with the arrival of the paddle steamer Richard Smith in the harbour of the capital, Charlottetown. ${ }^{7}$ This small, Nova Scotia built vessel, operating out of Pictou, was the first of several owned by the General Mining Association. ${ }^{8}$ Within two years, the Island legislature had passed legislation to promote steam on the Strait by providing for a contract of up to $£ 500$ for the conveyance of mails to Nova Scotia and New Brunswick conditional on a good and sufficient steam vessel of at least fifty horsepower with good accommodation for passengers, properly equipped and manned. ${ }^{9}$ This act, providing a mail subsidy, was renewed and expanded several times over the next ten years. In 1832, Samuel Cunard proposed a steamer route from Pictou to Miramichi stopping at Charlottetown and Bedeque. ${ }^{10}$ When the service commenced in the spring of that year it was the ninety-foot vessel Pocahontas owned by the General Mining Association which began to provide a regular service. ${ }^{11}$ The following year the

\footnotetext{
5 Andrew Hill Clark's volume on historical geography, Three Centuries and the Island (Toronto: University of Toronto Press, 1959), remains one of the best sources for the Island's history for this period although other texts provide more detailed coverage of political events and activities.

6 Steamships were running on the sheltered Saint John River and across Halifax harbour before 1820 and began steam service across the Bay of Fundy in 1826. Andrew H. Wilson, Some Early Canadian Steamboats (Ottawa: Engineering Institute of Canada, Engineering History Paper \#67, 2017; James Croil, Steam Navigation and its Relation to the Commerce of Canada and the United States (Montreal: The Montreal News Company, 1898), 344.

Colonial Patriot (Pictou), 1 May 1830.

8 The General Mining Association owned at least five steamers in the period 1830 - 1850, all but one built in Nova Scotia. While there have been a number of articles concerning the activities of the company, its role in marine transportation and communications in the region is rarely noted and has not been the subject of study.

9 "An Act to provide for the Conveyance of the Mails between Charlottetown and Pictou by a Steam Vessel," 2 William IV c 26, Acts of the General Assembly of Prince Edward Island, 1832.

10 Royal Gazette (Charlottetown), 7 February 1832.

11 The Pocahontas continued to sail the Strait but not as the PEI packet. She stayed on the shipping
} 
company acquired the steamer Cape Breton, which became the first British-built steam powered vessel to cross the Atlantic although, as with other early steamers, much of the crossing was made under sail. ${ }^{12}$ The Cape Breton was sold in 1838 to Samuel Cunard's brother Joseph, and continued to serve the Strait ports but two years later she returned permanently to England.

By the early 1840s, the advantages of regular and dependable steam service had become obvious to the Island. ${ }^{13}$ Commercial activities were aided by speedy mail service and a dependable schedule between specified ports for both passengers and freight. The ability to make the crossing in a reasonable time in spite of adverse or absent winds was a bonus. Charlottetown was well-positioned on Northumberland Strait to serve as a stopping point between two rapidly developing centres, Pictou and Miramichi. The former was already an established centre for mining and industrial development, while the latter was the only really accessible port on the coast of north-east New Brunswick, and in the 1840s the importance of the community was growing through the timber trade. Mail routes and roads had been developed between Pictou and Halifax, and communications by sea up and down Northumberland Strait were far easier than those overland in New Brunswick. For much of the period the best route between Saint John and Miramichi was a steamer across the Bay of Fundy to Annapolis or Windsor, followed by road to Halifax, Truro and Pictou and then by packet up the Strait. ${ }^{14}$

In 1840 the PEI House of Assembly had requested that steamers carrying the mails from Pictou to Quebec stop at Charlottetown, but Samuel Cunard, who was the contractor for the service declined to do so, citing the delays this would cause. Instead he offered to put a steamer on the Northumberland Strait route for $£ 1800$ per annum for twice monthly service. This was followed by an offer from the owners of the Pocahontas for two trips per week at $£ 400$ Halifax currency per annum. ${ }^{15}$ New Brunswick was also prepared to encourage a steamer service and in 1840 provision was made in the appropriation legislation for an annual grant of $£ 350$ for a weekly steamer service between Miramichi, Charlottetown and Pictou. The grant had a number of requirements concerning stopping places, times and minimum horsepower and it unlikely that any funds were paid out for the five-year

\footnotetext{
register until 1853 when the registration was closed as the vessel had burnt. Martell states that the Pocahontas was owned by the PEI Steam Navigation Company but there is no evidence that this is correct. Martell, "Intercolonial Communications," 188.

12 https://sailstrait.wordpress.com/2015/02/21/first-across-the-north-atlantic/ accessed 29 October 2019.

13 The economic and social impacts of steam technology on the shipping industry are discussed in John Armstrong and David M. Williams "“A New and Very Modern Business': The Traffic and Operations of the Early Steamship," in their The Impact of Technological Change: The Early Steamship in Britain (St. John's: International Maritime Economic History Association, Research in Maritime History 47, 2011), 183-203.

14 Martell, "Intercolonial Communications."

15 Prince Edward Island, Journal of the Legislative Council, 1 February 1841, Appendix No. 8.
} 
term of the legislation. ${ }^{16}$

At the end of the 1840 shipping season, when the Cape Breton returned to England, the lack of a steamship to fulfil the mail contract for the following year was seen as a threat to the Island's prosperity. The return to a sailing packet "would be not a little mortifying, and after so long having enjoyed the advantages derived from steam intercourse with the neighbouring ports, but we do not despair that something may be done." 17 While a service between Pictou, Charlottetown and Miramichi was desirable there was pressure on the Island to ensure that additional PEI ports were included in the routing of the vessels. In the House of Assembly debate on the appropriation for the mail subsidy in 1841, an attempt by local politicians to add service to Bedeque, which lay between Charlottetown and Miramichi, and Georgetown, the main port for the eastern section of the colony, as a condition of the grant, was defeated. ${ }^{18}$ However the proposal would re-appear the following year in a different form.

The feared reappearance of a sailing packet was delayed by again awarding the 1841 mail contract to the proprietors of the aging Pocahontas. The Colonial Herald noted on her first appearance in Charlottetown that year that the steamer had been "greatly improved in appearance but not, we believe, in her sailing qualities." ${ }^{19}$ In addition to her crossings between Pictou and Charlottetown, she included fortnightly visits to Georgetown, but no mention is made of any regular voyages to Miramichi. On occasion, the Pocahontas was replaced by the smaller and older steamer Albion. ${ }^{20}$ However by the end of the season, in spite of the supposition that the Albion would receive new boilers over the winter, it was clear that there was little enthusiasm on the Island for having either vessel continue on the route for another year. ${ }^{21}$

With off-Island interests showing little desire to improve the Northumberland Strait service, and faced with the withdrawal of a steamer service on which the Island had come to depend, some in the colony began to look to their own resources. One solution lay in a relatively new form of corporate ownership for Prince Edward Island - the joint stock company. ${ }^{22}$ Sarah Palmer notes that the high initial costs

16 "An Act to appropriate a part of the Public Revenue for the services therein mentioned," 3 Victoria c 59, Acts of the General Assembly of Her Majesty's Province of New Brunswick, 1840.

17 Colonial Herald (Charlottetown), 31 October 1840.

18 Colonial Herald (Charlottetown), 3 March 1841.

19 Colonial Herald (Charlottetown), 8 May 1841.

20 Colonial Herald (Charlottetown), 31 July 1841.

21 Colonial Herald (Charlottetown), 27 November 1841.

22 The idea of a joint stock steamship company may have been top of mind as one had been proposed in 1840 in Newfoundland to operate a St. John's to Halifax steamer service, Colonial Herald (Charlottetown), 26 September 1840. The same year the first Nova Scotia incorporation act relating to steam navigation was passed. "An Act to Incorporate the Bay of Fundy Steam Navigation Company," 3 Victoria c 43, Acts of the General Assembly of the Province of Nova Scotia, 1840. The first such act in New Brunswick was passed in 1846, "An Act to Incorporate the Chignecto Steam Navigation Company," 9 Victoria c 44, Acts of the General Assembly of Her Majesty's Province of New Brunswick, 1846. 
of steamships and increased running costs placed steamship operation beyond the reach of individuals and small partnerships and that accordingly steamers became more marginal operations than sailing ships. Moreover the large amount of risk attached and the extreme consequences of failure were disincentives for small-scale entrepreneurs such as existed on Prince Edward Island. ${ }^{23}$ Some relief was provided by the emergence of joint stock company incorporation; however corporation ownership was not always synonymous with vessel ownership. Vessels continued to be held under fractional ownership although the corporation itself could hold all of the sixty-four of the vessel shares. This approach was slow to develop in the first half of the nineteenth century but in the United Kingdom it gradually became a viable alternative to the traditional preferred fractional ownership model. ${ }^{24}$ In some cases a mixed model was adopted with vessels owned fractionally by individuals and held in trust or leased to incorporated companies. ${ }^{25}$ Under the scheme of limited liability offered by the corporate model individual investors were liable only to the extent of their shareholding commitments and their other assets were protected in the event of failure of the company. ${ }^{26}$ In case of failure creditors were allowed access only to the assets of the company itself and not those of individual shareholders.

Dissatisfaction with the Nova Scotian steamer service led to an October 1841 public meeting called in Charlottetown to consider "the practicality of ensuring regular communication with the neighbouring colonies by means of a steam boat competent to carry out the intentions of the House of Assembly." The meeting was presented with information from a Mr. Gurney described as "an engineer lately arrived from England" who told those gathered that a good return on investment was possible should a steam boat company be formed. He cautioned however, that the benefits should not accrue to any one individual and it "would be a dishonour to colony if capitalists from other colonies or the mother country carry away

23 Sarah Palmer, "Experience, Experiment and Economics: Factors in the Construction of Early Merchant Steamships," in Keith Matthews and Gerald Panting, eds., Ships and Shipbuilding in the North Atlantic Region (St. John's: International Maritime Economic History Association, Research in Maritime History 47, 2011), 234.

24 John Armstrong and David M. Williams, "The Steamship as an Agent of Modernization, 18121840," in their The Impact of Technological Change: The Early Steamship in Britain, 175; Edwin Green, "Very Private Enterprise: Ownership and Finance in British Shipping" in Tsunehiko Yui and Keiichiro Nakagawa, ed., Business History of Shipping (Tokyo: University of Tokyo Press, 1985), 219-248. I am indebted to William Glover for clarification of this point.

25 A number of different ownership models are discussed by Walter Lewis in "Line Development and Passenger Steamboat Trade on Lake Ontario and the Upper St. Lawrence River, 1829-1875," The Northern Mariner/Le marin du nord 29: 2 (Summer 2019), 135-48. Although the article deals with shipping lines many of the observations also apply to companies with single vessels. There appears to have been no direct government participation in any of the companies noted by Lewis.

26 Suspicion about the mechanism may have lingered. A Nova Scotia steamship company incorporated in 1851 made shareholders liable for double their stockholdings. "An Act to Incorporate the Halifax and Annapolis Steam Navigation Company," 14 Victoria c 19, Acts of the General Assembly of the Province of Nova Scotia, 1851. 
the profits." If local investors did not act, the venture would fall into the hands of strangers. He advised that the route to success was to cooperate and form a company. In the small market, once the need was met by one company, competition would not occur. A committee, composed primarily of local merchants and shipowners, was formed to look into the details of the proposal and to report back in a matter of weeks. ${ }^{27}$

The following month, after reviewing Gurney's financial projections, the committee reported that there would be a return on investment of $9 \frac{1}{2}$ percent on an investment of $£ 7,000 .^{28}$ This profit estimate was in addition to a reserve of $£ 400$ per annum for depreciation of the vessel. The projections included revenues of $£ 932$ on the Charlottetown-Pictou route, $£ 1500$ on the Charlottetown-Miramichi route, and $£ 200$ in income from Bedeque. Also on the revenue table were grants for mails of $£ 552$ from PEI, $£ 350$ from New Brunswick and $£ 150$ from Nova Scotia. Many of these figures were to prove problematic. However, the optimism of the meeting was such that a motion to form a company was hastily carried and some seventy shares were subscribed the same day. ${ }^{29}$

The immediate level of enthusiasm was not sustained and a month later William Swabey, chairman of the committee, complained in the Colonial Herald that, notwithstanding the large number of individuals requesting the initial meeting, only a limited number of Islanders had actually committed to buying the stock of the company. He worried that "the real interests of the Province should be a matter of great indifference to its inhabitants." The committee would continue its work, but he pleaded for a show of support for the venture. "Among all our patriots, so ready to denounce the prospects of the Island, can none be found to aid in its advancement?"30 Furthermore, in the proposal a number of shares had been allocated for purchase by residents of the neighbouring colonies but none had been taken up. ${ }^{31}$

Letters for and against the creation of a joint stock company began to appear in the newspapers. "Halitus" enumerated and countered the supposed objections, including the example of the recently-failed Steam Mill Company, ${ }^{32}$ the questionable basis of the report's calculations, and the probability of competition; and concluded that even if the venture did not pay, the colony would profit "by increasing the

\footnotetext{
27 Colonial Herald (Charlottetown), 20 October 1841.

28 It is not always clear which of several currencies are being used in reports and accounts. At the time amounts could be quoted in Sterling, Halifax Currency, or Island Currency. Conversions between the three currencies also varied over the period. In general, however $£ 100$ Sterling was equivalent to $£ 125$ in Halifax currency or $£ 140$ to $£ 150$ Island currency. See A.B. McCullough "Currency Conversion in British North America," Archivaria 16 (Summer 1983), 89.

29 Colonial Herald (Charlottetown), 13 November 1841.

30 Colonial Herald (Charlottetown), 11 December 1841.

31 Nor would they be, as the shareholder ledger shows an almost total lack of off-Island participation.

32 The Steam Mill Company was the first incorporated enterprise in the Colony and was a failure which left many unsatisfied creditors. See https://sailstrait.wordpress.com/2017/03/15/ steampower-on-the-charlottetown-waterfront/ accessed 4 April 2020.
} 
value of property and of the productions of the soil and by the increasing number of consumers brought to our fertile shores by means of the establishment of regular steam communication. ${ }^{33}$ "Peter Packthread" argued that if the company was such a good investment, why then would the capitalists of the community want to have a broad based ownership which carried the risk of opposed interests and threatened collisions within the company? $?^{34} \mathrm{~A}$ week later "Vapor" countered that wide support would spread the benefits of the anticipated success and he saw the venture as the beginning of a new era. He called for Islanders to meet the challenge; "let all aid in the project; let's all have it at heart, let the farmer and the merchant and the mechanic alike contribute their aid and they will not stop at so small an end as a successful Steam Company. That will be the stepping stone to a long course of public improvements which shall at length raise Prince Edward Island to that importance which its natural advantages so pre-eminently entitle it to." ${ }^{35}$

Whether through a renewed sense of insular patriotism or in an actual belief in the economics and rosy future of the venture itself, interest in the shares began to increase. A major boost was the decision of the colonial government to support the initiative through purchase of a large block of shares. The reasons and political will behind this decision does not seem to be documented but it is worth noting that a number of directors of the proposed company were also members of the colony's Legislative Council and other shareholders sat in the House of Assembly. At the same time the venture also began to pick up investors across the Island. By the time of a meeting of shareholders in early April of 1842, 410 of the 450 shares had been taken up and it was felt that there was every prospect that the remaining shares would soon be subscribed ${ }^{36}$ The government decision to purchase shares helped with capital investment and provided much of the funding to acquire the company's major capital asset - a suitable steamer to carry passengers, the mails, and cargo across the Strait. The commitment to a continuing mail subsidy and the payments for passenger and other services provided to the colonial administration would contribute to operating revenue.

The legislation providing for government participation in ownership passed with only a few minor amendments in the spring 1842 session of the colonial legislature. The originating shareholders named in the act, some fifteen merchants and ship owners, almost all of whom were from Charlottetown, became "a Body politic and corporate" under the name "The Prince Edward Island Steam Navigation Company." ${ }^{37}$ The act that created the Steam Navigation Company was among the first in the colony to provide for incorporation. ${ }^{38}$ The capital stock was divided

\footnotetext{
33 Colonial Herald (Charlottetown), 27 November 1841.

34 Colonial Herald (Charlottetown), 11 December 1841.

35 Colonial Herald (Charlottetown), 18 December 1841.

36 Colonial Herald (Charlottetown), 19 March, 9 April 1842.

37 "An Act for the Incorporation of the Prince Edward Island Steam Navigation Company," 5 Victoria c 2, The Acts of the General Assembly of Prince Edward Island, 1842.

38 The only other incorporation legislation during the period was the 1837 "An Act to Incorporate the Steam Mill Company of Charlottetown," 7 William IV c 8, The Acts of the General Assembly of
} 
into 450 shares, each to be valued at $£ 20$ creating a nominal value of $£ 9,000$. The preamble recited the commitment of the government to purchase shares in the company but it also created specific performance obligations. Government support was dependant service on the following routes and schedule: "the said company will engage to run their Boat once a week from Pictou and Charlottetown to Miramichi touching at Bedeque once a fortnight, on her way to and from the latter place, and calling at Georgetown once a fortnight." It is worth noting that Georgetown had not been identified as a stopping port in the original discussion of the enterprise and was clearly one of the obligations added to support government involvement. A second piece of legislation authorized the appointment of three commissioners to manage the 150 government shares. ${ }^{39}$

The government chose Charles Hensley of Charlottetown, Joseph Pope of Bedeque and Joseph Wightman of Georgetown. ${ }^{40}$ It may have been politically expedient to appoint one individual from each of the colony's counties but every one of them had potential conflicts as they all owned private shares in the enterprise. Pope and Hensley were also selected by the government to be the ex officio members of the board of the company. The mingling of the public purposes of the company and the private operational considerations was to become a problem early in the company's short history. The preamble to the act also referenced an expectation which was to provide another challenge. It noted that the legislatures of Nova Scotia and New Brunswick "have heretofore tendered respectively certain sums of money also to be paid annually, in encouragement of such an undertaking." These commitments would prove to be elusive as they also carried specific performance obligations which would challenge the company and for several years remain just out of reach.

A key clause in the act limited the liability of the shareholders. "The Joint Stock and Property of the said Company shall be alone liable for the Debts and engagements of the Company." This limitation was a feature of incorporation and may have been a significant factor in attracting a large number of shareholders to the venture. Instead of exposing their complete holdings in the case of failure, any loss would be limited to the amount they had committed to the share purchase price.

As was the case with all legislation, the act was referred by the lieutenant governor to the Colonial Office for review and comment. Attorney General Robert Hodgson provided background noting that the act was of vital importance for the carrying of mails and trade with the neighbouring colonies. It did not establish

\footnotetext{
Prince Edward Island, 1837.

39 "An act to Authorize the appointment of Commissioners to manage certain Shares and Property in the Prince Edward Island Steam Boat Company, on behalf of the Government of this Colony," 5 Victoria c 3, The Acts of the General Assembly of Prince Edward Island, 1842. The error in reference to "Steam Boat Company" as opposed to "Steam Navigation Company" seems to have gone unnoticed.

40 Royal Gazette (Charlottetown), 16 August 1842.
} 
any exclusive privilege on the company and had been passed "with unanimous approbation of public opinion in its favour." The Colonial Office, after consulting with the Treasury advised Governor Huntley that the act should be left in operation. ${ }^{41}$

The Peake-Brecken papers in the PEI Public Archives and Records Office give a rare glimpse into the ownership and affairs of the company. A share register for the Prince Edward Island Steam Navigation Company shows that in contrast with the usual close partnership model for companies and vessels there was a broad base of ownership for the Steam Navigation Company. ${ }^{42}$ In addition to the 150 shares taken by the colonial government there are 112 names on the share register, accounting for 272 of the 450 available shares. There are a number of names that one might expect to see associated with a mercantile initiative. Leading Charlottetown shipbuilders and owners, merchants, and officials such as James Peake, T.H. Haviland, John Longworth, William Douse, Henry Stamper, W.W. Lord, Francis Longworth, William Yeo, and Andrew Duncan all signed up for shares. ${ }^{43}$ While a majority of the share-owners were from Charlottetown, the requirement in the legislation for service to Bedeque and Georgetown attracted investors from both of those smaller ports. There were more than a dozen men from the Bedeque area, and Georgetown was also well represented. Other owners were resident in smaller communities across the Island. The only non-Islanders on the list were land proprietors D.S. Rennie of St. John's Newfoundland and Sir George Seymour of London. Their shares were likely subscribed by their resident agents.

While the vast majority of those in the list subscribed for only one or two shares there were exceptions. James Peake and T.H. Haviland, both major ship owners and merchants, took ten shares each. There were a dozen others (mostly recognizable as merchants) with five shares apiece. The largest ownership was in the name of Charles Hensley, who had twenty shares in his own name and another five belonging to his son. In 1846 he acquired an additional thirteen shares. Hensley was one of the originators of the company and assumed a leadership role, serving as chair of the board of directors for most of the company's short history. Hensley was also one of the ex officio board members appointed by the government as well as one of the three commissioners managing the government shares. He had been an officer in the Royal Navy and in 1841 immigrated to Prince Edward Island

\footnotetext{
41 Huntley to Stanley 30 May 1842, The National Archives, Kew, UK, CO226/63/203, 213, 244.

42 Prince Edward Island Public Archives and Records Office (PARO), Peake- Brecken Papers Accession 2882 item 374 - share register Prince Edward Island Steam Navigation Company. Additional material relating to the company is found in PARO. Welsh and Owen Papers, Accession 3744. This material includes purchase and operating accounts for the St. George.

43 While many of these individuals are the subject of entries in the Dictionary of Canadian Biography the biographies generally concentrate on political activities and few mention their shipping interests. Only James Peake has attracted attention from marine historians. See Lewis R. Fischer " An engine yet moderate': James Peake, Entrepreneurial Behaviour and the Shipping Industry of Nineteenth Century Prince Edward Island," in Lewis R. Fischer and Eric W. Sager, eds., The Enterprising Canadians: Entrepreneurs and Economic Development in Eastern Canada ,1820-1914 (St. John's: Memorial University of Newfoundland, 1979).
} 
where he quickly became part of the colony's small elite. The following year he was appointed to the Executive Council.

With the passage of the legislation, the directors acted quickly. Francis Longworth Jr., one of the directors, was dispatched to England in May 1842 with the necessary funds to purchase a steamer. Shortly after his departure, it was reported that a competing proposal for operations on the Strait with a vessel called the John M'Adam was already underway. Owners of the John M'Adam advertised in English papers that it had been chartered to carry the mails between Pictou, Charlottetown and Miramichi. The John M'Adam was a large steamer built 1836 with accommodation for fifty in the best cabin and another thirty in the fore cabin. Set to depart Liverpool on 4 June, the vessel was delayed and then had to resort to sail for much of the trip as it ran low on fuel. ${ }^{44}$ The Colonial Herald dismissed the report of the mail contract as "private speculation" as there was no authority from the Island to enter into an engagement for the service. ${ }^{45}$ Fortunately for the Steam Navigation Company the John M'Adam did not, in fact, have the Northumberland Strait mail contract and although it arrived in Pictou early in September, it appears not to have visited either Charlottetown or Miramichi and was advertised as being for sale in late September $1842 .{ }^{46}$

Meanwhile in Liverpool, Longworth, perhaps frightened by news of the reported competition from the John M'Adam, moved quickly and decisively. By the end of July the directors were informed that he had committed the company to the purchase of the steam packet St. George. ${ }^{47}$ The "large and elegant" paddle steamer had been launched from the Wilson and Sons yard at Cornhill, now part of Liverpool, on 21 November 1831. She was built for the St. George Steam Packet Company, which had an active service between Liverpool and Irish ports such as Dublin and Cork. ${ }^{48}$ The single deck vessel had a tonnage of 157 tons and was 135 feet long by 20 in breadth. ${ }^{49}$ The 110 "horses power" engines were built by Fawcett Preston \& Co. of Liverpool. Its primary use was on the 120 nautical mile Liverpool to Dublin passage across the Irish Sea. Made obsolete by newer and larger vessels the ten year old St. George was on the market just when Francis Longworth was searching for a vessel for the newly formed Prince Edward Island Steam Navigation Company. The paddle steamer had been re-furbished with new boilers and new

\footnotetext{
44 The vessel in some reports is noted as the John McAdam. Leeds Mercury (Leeds, England), 7 May 1842; Morning Advertiser (London, England) 17 September 1842.

45 Colonial Herald (Charlottetown), 28 May 1842.

46 Colonial Herald (Charlottetown), 3 September 1842; Mechanic and Farmer (Pictou), 21 September 1842.

47 Colonial Herald (Charlottetown), 20, 23 July 1842.

48 Richard Greenwood and Fred Hawks, The Saint George Steam Packet Company 1821-1843 (Kendal, Cumbria, UK: World Ship Society 1995; Gore's Liverpool General Advertiser 24 November 1831; Dublin Evening Packet and Correspondent 24 November 1831.

49 The Register of Shipping for the year 1833 (London: Lloyd's Register, 1833); The New Mills List. Registered Canadian Steamships 1817-1930 over 75 feet. db.library.queensu.ca/marmus/mills/ accessed 23 October 2019.
} 


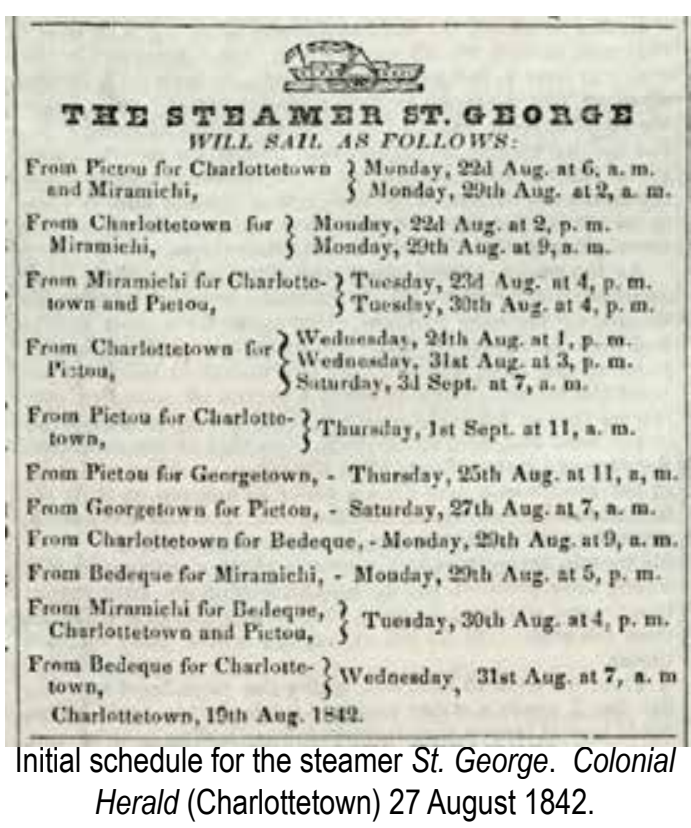

decks the previous year and had been newly coppered and provided with new sails. ${ }^{50}$ Following the purchase, the St. George was scheduled to leave Liverpool for St. John's and Charlottetown on 9 July, stopping at Cork for passengers. ${ }^{51}$

The steamer arrived in Charlottetown on 14 August 1842 after a passage of fourteen days from Cork, including a stop at St. John's. ${ }^{52}$ She was greeted by a cannon signal when spotted from the blockhouse at the mouth of the harbour and a large crowd had assembled by the time she drew up to Queen's Wharf. In spite of being heavily laden with coal for the Atlantic crossing, she was also able to bring a few passengers and freight. Things were not entirely perfect for, owing to "the intemperate habits of the Captain and Steward and the discontented state of some of the crew" some changes were necessary before service on the Strait began. A new master, Captain Mathewson, and a managing agent, Thomas Owen were hired. ${ }^{53}$ Owen was connected to a Charlottetown mercantile company and had knowledge of vessel operations and management. He and a clerk appear to have been the only shore-based staff of the company. With adjustments made and a new captain hired, the ship began her schedule only four days after her arrival. There was much excitement on the first few voyages. The first trip from Charlottetown to Pictou carried an amateur band and an overflow of passengers including some sixty in the party of directors and friends. On the second scheduled trip to the mainland the pre-occupation with arrangements led to the mail being forgotten and it had to be dispatched later in the day by sailing packet. ${ }^{54}$ Before the end of the month, the ship had also made its first return visit to Miramichi, steaming about twenty-two hours in each direction. ${ }^{55}$

At the close of operations in December that year, Charlottetown's Colonial Herald reported that to date, the venture had been more successful than it appeared.

\footnotetext{
50 New Brunswick, Journal of the Legislative Council, 1843, Appendix 11.

51 Southern Register and Cork Commercial Courier, 2 July 1842.

52 Arriving after the John M'Adam she would appear to have been only the third steamer to visit the port.

53 Royal Gazette (Charlottetown), 16 August 1842.

54 Colonial Herald (Charlottetown), 20 August 1842.

55 Colonial Herald (Charlottetown), 27 August 1842.
} 
In spite of facing "the difficulties inseparable from the first establishment of an undertaking of this description, together with the unprecedented depression, both here and elsewhere, during the past summer the state of things was "extremely gratifying to all concerned." ${ }^{56}$ However, even accounting for the short operating period of just over three months in 1842, there were some troubling figures presented at the first annual general meeting in February 1843. ${ }^{77}$

The purchase price of the St. George was $£ 3,580$ sterling - $£ 4,200$ when finalized. With the costs of passage added and a small amount of offsetting revenue from passengers and freight across the Atlantic, the net cost was $£ 5,466$ Sterling or just over $£ 8,000$ Island currency. This pretty well exhausted the capital for the venture, especially as some shares had been subscribed but not yet paid up and a few others remained unsold. There was worse news on the revenue side. Passenger money and freight and the amount received for liquor served aboard, as well as half the mail subsidy for the year still fell short of the expenses by more than $£ 400$. Part of the shortfall was blamed on the "general slackness and embarrassment of mercantile affairs" and the "unusually stormy and tempestuous season."

The financial report presented to the annual meeting looked at the revenues from each port. Weekly trips between Charlottetown and Pictou generated an average of just over $£ 26$ per trip and trips to Miramichi brought in an average of $£ 35$. Calling at Bedeque, however, yielded only about $£ 6$ per trip and trips from Pictou to Georgetown just $£ 4$ per trip. These figures suggest that the vessel was operating far from capacity and the large and luxurious vessel had excessive fuel and crew costs. It became obvious to the directors that they had a bigger and more expensive ship than the traffic warranted and without a significant increase in business, profit appeared unattainable..$^{58}$

The directors also flagged an emerging issue which was to plague the company until the end of its existence - the problems of meeting the expectation that came with government funding. Although they had "laboured earnestly and zealously to fulfil the demands and expectations of the different Legislatures: and it is with much regret that they have been compelled to declare their opinion of the utter impossibility for any one Steam Boat to accomplish all the conditions imposed on the Company by them."

In the financial accounts there were two lines to which no figures are attached. These were the sums that had been anticipated from the provinces of New

\footnotetext{
56 Colonial Herald (Charlottetown), 10 December 1842. The novelty of the enterprise, as well as the broad base of ownership, meant that unusually detailed newspaper accounts which included copies of material presented to the meetings appeared in the local press.

57 Although the Peake-Brecken papers contain some of the financial details and a summary of the annual report was reported in the Islander the whole report was attached to a funding request sent to the Legislative Council of New Brunswick and published in the New Brunswick Journal of the Council in 1843 as appendix 11. The full report was also printed in the Royal Gazette (Charlottetown), 21 February 1843.

58 On a more positive note the company seems to have been spared any major refit or repair of the ship notwithstanding the considerable strain that engines and boilers could put on a wooden boat.
} 
Brunswick and Nova Scotia to subsidize service to their ports. Neither colony had provided a subsidy, and without assured resources from the mainland provinces, it appeared that the venture would be severely compromised.

A significant change to the legislation was passed by the PEI legislature in 1843 provided some relief for the struggling company. For the "more regular conveyance of mails" the requirement of service to Georgetown was removed from the act. As compensation the government agreed to purchase the nineteen shares of investors from the Georgetown area and to purchase the remaining twenty-nine unsold shares in the company. This increased capital investment brought the government holdings up from one third to 44 percent of the total shareholding. ${ }^{59}$ In the debate on the legislation there was general support for the move but the comments of the Speaker in the debate showed that the public purposes of the company had not entirely been lost sight of; "he did not think that the majority of those who took shares in the Company did it solely for the sake of lucre, but with a more noble spirit, that of benefit to the Colony; and to prove to the neighbouring Provinces that their taunts were groundless; that we could have a boat of our own."60

By the end of the 1843 season, the situation had improved only slightly. Nova Scotia had provided a subsidy of $£ 200$ for that year, but had not acknowledged any financial response regarding the services in the year 1842. The situation in New Brunswick was unchanged where a vote for funds in the House of Assembly was opposed by the Legislative Council. In June the company received communication from New Brunswick that the attorney general had given an opinion that the Steam Navigation Company had neither a legal not an equitable claim for support. The directors responded by announcing the withdrawal of services to Miramichi ${ }^{61}$ However the St. George continued to make trips to northern New Brunswick, at first because it had outstanding obligations to deliver the mails, and later because the inhabitants of the Miramichi River towns were unwilling to see the voyages suspended. It was reported that they had started a subscription to indemnify the Steam Navigation Company in the event that the New Brunswick government failed to provide the requested subsidy. ${ }^{62}$

The operating accounts for 1843 were somewhat more encouraging with a very slight profit of $£ 14 .{ }^{63}$ This picture, however, masked the information that interest and insurance costs were not included in the total. There would be no

\footnotetext{
59 "An Act to alter and amend the several Acts herein mentioned relating to the Prince Edward Island Steam Navigation Company," 6 Victoria c 6, Acts of the General Assembly of Prince Edward Island, 1843,

60 Royal Gazette Supplement, 28 March 1843. The Speaker at the time was Joseph Pope who was a shareholder in the company as well as a commissioner regarding the management of the government shares and an ex officio member of the board.

61 Islander (Charlottetown), 30 June 1843.

62 Royal Gazette (Charlottetown), 11 July 1843, 18 July 1843. About 50 percent of the Miramichi subscription had been raised by this date and the report stated that the rest would be forthcoming without difficulty.

${ }^{63}$ Islander (Charlottetown), 23 February 1844.
} 
dividend paid to shareholders. The directors tried to put the best spin on things. Notwithstanding the unfavourable financial information "one almost redeeming consolation is that the public is deriving, and we hope will continue to derive, incalculable advantages from the existence of the Company; and from the regular and commodious communication, by means of its vessel, with the neighbouring provinces." 64

The restrictions on the company established by the incorporation legislation were further relaxed by an amendment in 1844, which allowed the company to alter destinations or routes without seeking further permission from government. The directors would have the freedom to act in ways "most beneficial and advantageous for the interests of this Colony; and of the Shareholders in the said Company." ${ }^{2} 5$ Before the 1844 shipping season opened there was some encouraging news. The funding request to New Brunswick to subsidize the trips to Miramichi had been successful and the legislature in Fredericton had agreed to a grant of $£ 75$ for the 1842 season and $£ 360$ for 1843 establishing, in the words of the editor of the Royal Gazette, "the honourable character of its legislature and at the same time dealing liberal justice to the Steam Company of this Island." 66 Notwithstanding the newspaper report, the company had not, at the time, received any official notice of the grant and its advertisement at the beginning of the season included the following caution; "No official intelligence having been received from New Brunswick or Nova Scotia, the Directors are unable as yet to determine the plan of the St. George's operations for the ensuing summer." ${ }^{67}$ In a letter to the Royal Gazette, "Viator" urged the directors to consider occasionally sending the St. George to Shediac. By taking the mail coach to the Bend of the Peticodiac, passengers could travel from Charlottetown to Saint John in as little as 24 hours. ${ }^{68}$ By June, however, the subsidy matter was resolved and a schedule of regular trips to Miramichi (calling at Bedeque on the up-voyage), had begun. ${ }^{69}$

At the end of 1844 the news was again discouraging and early in 1845 the annual general meeting was told that "the present traffic between the Ports of Pictou, Miramichi and Charlottetown is barely sufficient to bear the expense of keeping the St. George upon the station, and is altogether unproductive of profit for the Shareholders." 70 The meeting empowered the directors to negotiate the sale of the St. George "upon such equitable terms as a due consideration, of all

\footnotetext{
64 Royal Gazette (Charlottetown), 20 February 1844.

65 "An Act to alter Three several Acts relating to the Prince Edward Island Steam Boat Company," 7 Victoria c 9, Acts of the General Assembly of Prince Edward Island, 1844. The preamble to the act notes the desirability of having a steamer meet at the Gut of Canso with a steamer contracted by the British government to run between Halifax and St. John's. The act did specifically required weekly service between the Island and Pictou.

${ }^{66}$ Islander (Charlottetown), 12 April 1844 (quoting a report from the Royal Gazette).

67 Islander (Charlottetown), 26 April 1844.

68 Royal Gazette (Charlottetown), 30 April 1844.

69 Islander (Charlottetown), 6 and 14 June 1844; Miramichi Gleaner, 23 October 1844.

70 Royal Gazette (Charlottetown), 11 February 1845.
} 
the circumstances may appear advisable to them."71 Faced with this decision, the government prepared to abandon their stake in what was obviously a sinking ship. The legislature was presented with legislation stating in a preamble taken almost word for word from the director's report that "... the present traffic is scarcely sufficient to bear the expense of maintaining the vessel on station and she is altogether unproductive of profit to the shareholders and it is advisable that vessel be sold." The 1842 legislation prevented the government shares from being sold at less that the purchase price but the new bill allowed that the shares might be sold for less than cost, but provided that any proceeds from the sale of government shares could be directed to the purchase of a new vessel "in conjunction" with the company. ${ }^{72}$ In opening consideration of the bill in the Legislative Council William Swabey, a councillor and a company shareholder blamed the New Brunswick government for the company's problems by withholding their grant funds because the St. George's visits to the Miramichi were less frequent that the grant conditions required. Although the future of the company looked grim, Charles Young, another councillor who also held shares invoked a larger interest. "the Boat had been started by private individuals, from public motives, and for the purpose of forwarding the general interests of the community, and he trusted it was not the intention of this Legislature to allow the Shareholders to suffer a loss of any of their capital." 73 The legislation passed but notwithstanding the several declarations of public motives of the shareholders it was clear that the colonial government's experiment in the steam ship business was at an end.

Although the St. George was advertised for sale, the company continued to maintain service, including twice a month trips to Miramichi, for the 1845 season. ${ }^{74}$ A hoped-for subsidy from Nova Scotia was announced but it carried the condition that the vessel add Cape Breton to her route, a risky and unacceptable additional cost, and so the only funds received from governments were the mail subsidies of $£ 514$ from Prince Edward Island and $£ 247$ from New Brunswick. Passengers and freight added $£ 1522$ to the revenues but there was still a loss of over $£ 100$ on operations.

The uneconomic situation as regards traffic at Bedeque continued. The Miramichi Gleaner reported on one visit of the St. George to Bedeque where not a single passenger embarked and the only freight was a basket of hen's eggs. ${ }^{75}$ It had been clear for some time that the St. George was too big and too expensive. The Morning News and Semi-Weekly Advertiser warned however, that in the advanced state of commercial and trading affairs of the Island return to a sailing vessel could

71 Morning News and Semi-Weekly Advertiser (Charlottetown), 18 February 1845.

72 "An Act to authorize the sale of government shares in the steam boat St. George," 8 Victoria c 12, Acts of the General Assembly of Prince Edward Island, 1845.

73 Royal Gazette (Charlottetown), 22 April 1845.

74 Islander (Charlottetown), 18 October 1845.

75 Miramichi Gleaner, 10 May 1845, reprinted in Islander (Charlottetown), 23 May 1845. 
not be an improvement. ${ }^{76}$

In an attempt to secure more revenue a joint memorial from the PEI House of Assembly and the Legislative Council in 1844 was forwarded to the imperial authorities seeking additional funding to ensure the continued operation of the mails so as to "prevent the inconvenience and injury which an abandonment of the present communication would inflict." ${ }^{77}$ Even though the memorial was supported by the lieutenant governor who warned that the losses of the company threatened its future unless assistance was provided, the response received and tabled the following legislative session was a disappointing "no" as all of the net postage proceeds were already paid into the Colonial Treasury and no additional funds from Great Britain would be provided. ${ }^{78}$

The St. George kept up her regular schedule until the end of 1845, with trips once a week between Charlottetown and Pictou, and trips to Miramichi stopping at Bedeque twice a month. At the end of October the St. George was sold to Quebec merchant and ship owner William Stevenson and left for Miramichi and Quebec. ${ }^{79}$ The schooner Caledonia was contracted to carry the mails for the rest of the season.

Although without a ship, the company continued to exist. Late in 1845, James Peake wrote to William Stevenson having heard that Stevenson planned on putting the St. George on a route from Quebec to Gaspe. Peake expressed a hope that the merchants of Miramichi would put on a boat to call at Pictou and Charlottetown to meet the boat at Gaspe. Apparently the report was in error and no such route was put in place.$^{80} \mathrm{~A}$ special meeting of the company was held in January 1846 to consider the possibility of providing a replacement for the St. George. Charles Hensley was in the chair and he stated he had confidence that with a smaller and faster boat the company could be profitable and that he would increase his investment in the venture. T.H. Haviland and James Peake told the meeting that they too, would buy up shares, at the price the current assets would bring, of those wishing to leave the Company ${ }^{81}$ In the belief that a smaller and more efficient vessel would make the Company successful a resolution was passed that the directors procure "a Steam Boat of 50 or 60 horses' power, as may appear most advisable, and of a speed equal to 11 knots" be procured. ${ }^{82}$

\footnotetext{
76 Morning News and Semi-Weekly Advertiser (Charlottetown), 5 November 1845.

77 Prince Edward Island Journal of the Legislative Council, 16 April 1845.

78 Lieutenant-Governors dispatches Huntley to Stanley, 22 January 1844, Library and Archives Canada, Ottawa, RG7, G\&D Vol 5; Prince Edward Island Journal of the Legislative Council Appendix \#9 Gladstone to Huntley 26 January 1846.

79 Stevenson had a long connection with Prince Edward Island, being the owner of several vessels used in Captain Bayfield's hydrographic surveys. https://sailstrait.wordpress.com/2015/10/18/ gulnare-a-significant-name-in-canadian-marine-history/ Islander (Charlottetown), 1 November 1845 .

${ }^{80}$ Peake to Stevenson 28 November 1845, PARO, Peake-Brecken Papers Accession 2881 item 379.

81 Royal Gazette (Charlottetown), 20 January 1846.

82 Morning News and Semi-Weekly Advertiser (Charlottetown), 24 January 1846.
} 
The company decided to send Captain Mathewson, late of the St. George, to England with instructions to find a suitable boat. ${ }^{83}$ Peake contacted Stevenson again in May suggesting that Stevenson might be interested in putting the Pocahontas back on the Charlottetown - Pictou route but he later learned that Stevenson had disposed of the vessel. Peake was also in contact with Thomas Bolton of Halifax who was also seeking a steam vessel. Peake wrote that the company had been "entirely defeated in all our endeavors to procure a boat to carry the mails and passengers and shall I fear be at the mercy of the winds at least for the present season." ${ }^{44}$

The news that the company was in financial distress was certainly noticed by the shareholders in the Bedeque area. Realizing that stops at that port were unlikely to be continued even if the company procured another vessel, they petitioned to have their shares purchased by the government as had been done a year earlier with regard to the owners from Georgetown. This time the government, realizing that the problems were significant and unlikely to be resolved, refused the request. ${ }^{85}$

On 28 March 1846, the Island's colonial secretary placed an advertisement in several newspapers, both on the Island and the mainland, seeking "a good and sufficient Steamboat of not less than 50 horses power" to carry the mails between Charlottetown and Pictou." "86 A clause in that year's Appropriation Act allowed for a subsidy of $£ 600$ "should a steam boat be placed on station and perform a similar service to that performed by the boat of the Steam Navigation Company." ${ }^{87}$ No satisfactory offers were forthcoming. ${ }^{88}$

In the absence of steam service, the sailing packet Caledonia once again carried the colonial mails and passengers. Near the end of the 1846 season the Islander voiced what probably was a commonly held sentiment:

Charlottetown, in point of accommodation for passengers and mails between this port and the neighbouring Province, has retrograded at least fifteen years. How long is this state of things to last? We do sincerely hope that ere another Summer passes we shall have another Steamboat to take the place of the St. George. Some of our leading characters and monied men have recently had an opportunity of experiencing the inconvenience arising from the knocking about in the gulf, with contrary winds, in a

\footnotetext{
83 Islander (Charlottetown), 29 November 1845.

84 Peake to Bolton 4 May 1846, PARO, Peake-Brecken Papers. Accession 2881 Item 379.

85 Prince Edward Island, Journal of the Legislative Council, 6 March 1846.

$86 \quad$ Islander (Charlottetown), 4 April 1846.

87 "An Act appropriating certain Monies therein mentioned for the Service of the Year of Our Lord One thousand Eight Hundred and Forty-six," 9 Victoria c 29, The Acts of the General Assembly of Prince Edward Island,1846.

88 The General Mining Association steamer Albion had been an occasional visitor to Charlottetown in the period 1843-1845 and in some instances carried the mails but it was unlikely she met the power requirements of the advertisement. The eighty-foot vessel had been built in Pictou in 1835 and was used primarily as a local tug or for trips between Pictou and Cape Breton.
} 
sailing vessel, and we earnestly hope it may be the means of stimulating them to exertion in the procuring of another Steamboat. ${ }^{89}$

The last regular annual meeting of the Prince Edward Island Steam Navigation Company took place on 9 February 1847. Those present were informed that the company had unsuccessfully sought a steam boat in England, Scotland, Quebec and New Brunswick. Blaming the increased cost of machinery for failure to either buy or have built a boat built, they upped the ante in their direction to agents in England to find a boat of not less than fifty horse power at a cost up to $£ 4500$ sterling "or even a few hundreds beyond that amount."

The gap in steam service in 1846 had not gone unnoticed in the region. In early March 1847 W.H. and R.L. Scovil of Shediac advertised that the iron steamer Conqueror would begin service between Pictou, Charlottetown, Bedeque and Shediac as soon as navigation was clear. ${ }^{91}$ The Glasgow-built Conqueror was only two years old and was a little more than half the size of the St. George, 85.5 feet by 17 feet. She too, was a paddle wheeler and displaced 118 tons. The advertising for the service may have been a little premature as the vessel took fifty-six days to cross from England to Shediac. ${ }^{92}$ It was not until 18 June that she made her first visit to Charlottetown. The editor of the Islander observed "Though somewhat deficient in accommodation, she is said to possess the very necessary qualification of speed. "93 While she operated for the remainder of 1846 and throughout the 1847 season she did not return in 1848 and the owners soon disposed of the vessel which saw out the rest of its days as a tow boat in Saint John. ${ }^{94}$ The packet between Charlottetown and Pictou in 1848 was the schooner Peri. It was described as "a very handsome coppered and copper-fastened clipper built schooner, tastefully fitted, up with commodious apartments." 95 It was not, however, a steamboat.

A general meeting of the company was called in July 1847 "for the purpose of adopting such steps as may be advisable and necessary for the future Government of the Company." ${ }^{.96}$ By this time the stores and other assets of the company had been sold by auction and the accounts made up. ${ }^{97}$ Noting that the efforts to procure a vessel with the desired forty horsepower and limited to an expenditure of $£ 4500 \mathrm{had}$ not been successful and observing that the steamer Conqueror had been operating on the route, but without knowing if that venture would be a success, the directors

\footnotetext{
89 Islander (Charlottetown), 30 October 1846.

$90 \quad$ Islander (Charlottetown), 5 February, 12 February 1847.

91 Islander (Charlottetown), 1 March 1847.

92 Islander (Charlottetown), 11 June 1847.

93 Islander (Charlottetown), 18 June 1847.

94 It appears that the routing of the Conqueror did not include Miramichi. Its westernmost point on the schedule was Shediac. Islander (Charlottetown), 16 July 1847 and Islander (Charlottetown), 3 March 1848. The registration on the vessel was closed in 1858.

95 Islander (Charlottetown), 5 May 1848.

96 Islander (Charlottetown), 2 July 1847.

97 Royal Gazette (Charlottetown), 3 August 1847.
} 
felt it premature to dissolve the company. However they acknowledged that many shareholders wished to avoid any further expenditure. The directors resolved that any shareholders who wished to be discharged from further responsibility could receive the current value of their shares. The settlement offered was $£ 619$ s Island currency per share. ${ }^{98}$ What may have been the final meeting of the directors was held in November 1847. A large number of the shareholders had retired from the company under the July offer and it was decided that the remaining shareholders would be permitted to cash their shares on the same terms. ${ }^{99}$ As no further news about the company has been found this decision probably represents the effective dissolution of the Prince Edward Island Steam Navigation Company. ${ }^{100}$ Although the shareholders lost much of their investment the company appears to have cleared its debts and the discontinuance of the Steam Navigation Company was not accompanied by further failures on the part of suppliers and creditors.

The history of the steamer St. George after leaving Charlottetown was less than glorious. She operated as a tug and towboat in Quebec until 1850, when she was sold to Newfoundland interests. On her passage to St. John's, she ran out of fuel and was forced to land at Ingonish, Cape Breton under sail. Her final voyage took place in January 1852 when she left St. John's bound for Cork. She disappeared on the North Atlantic and was never heard from again.

For the next decade and a half, a series of relatively short lived attempts were made to develop a profitable steamer service across Northumberland Strait. After the Conqueror and the sailing vessel Peri, the steamer service returned with an Island owner in 1849 when James Peake put the paddle steamer Rose on the route. ${ }^{101}$ In 1853 it was replaced by a New Brunswick based steamer, the Fairy Queen, which was wrecked with the loss of ten lives late in the season. The next year another New Brunswick boat, the Lady Le Marchant, was put in service and that vessel was replaced in 1857 by the Westmorland, ${ }^{102}$ which also had a New Brunswick owner. It was not until the development of the second Prince Edward Island Steam Navigation Company in 1863 that there was a sustainable steamer service across Northumberland Strait. ${ }^{103}$

The first Prince Edward Island Steam Navigation Company had faced a number of challenges. The vessel it was rushed to acquire in England was almost certainly

\footnotetext{
98 Islander (Charlottetown), 6 August 1847.

99 Islander (Charlottetown), 26 November 1847; Royal Gazette (Charlottetown), 30 November 1848.

${ }^{100}$ The 1851 consolidation of the acts states "The P.E. Island Steam Navigation Company having been dissolved it is unnecessary to insert this act."

101 https://sailstrait.wordpress.com/2015/03/15/the-wines-were-also-very-good-jamespeake-and-the-steamer-rose/ Accessed 23 October 2019.

${ }^{102}$ H.T. Holman, "Christopher Boulton's Westmorland and the Northumberland Strait Steamer Service" Argonauta 2020 (forthcoming).

103 The second Prince Edward Island Steam Navigation company was reorganized under Dominion legislation as the Charlottetown Steam Navigation Company in 1890 and was wound up in 1916 following the creation of a government operated, year round rail ferry service.
} 
larger and more expensive to operate than the traffic was able to bear. The market for passenger and freight service on Northumberland Strait was dependant on an assumption that the entire region would enter an era of increased prosperity. With a downturn in the economy in the early 1840s, most severely felt in the timber trade in Miramichi, but to a lesser extent on Prince Edward Island, the anticipated increase in intercolonial trade failed to materialize. For the venture to succeed, subsidy contributions from New Brunswick and Nova Scotia had been expected but New Brunswick was slow to participate, and Nova Scotia had requirements that the struggling company was unable to fulfil. Perhaps most burdensome was the obligation placed on the company by the PEI colonial government's participation in the scheme. The benefit of increased capital investment through government ownership of shares, as well as ownership participation by many small investors across the colony, carried with it expectations of service to the ports of Georgetown and Bedeque which proved unprofitable. The model of the joint stock company had been put to a good test and while losses were not disastrous, especially when spread across a broad base of investors, it was not embraced on Prince Edward Island as a development mechanism for many years. For the mercantile interests of Prince Edward Island the experience with the Steam Navigation Company had been a cautionary tale. 